\title{
Olaf Sievert
}

\section{Einfache Wahrheiten zählen}

\section{Beratung mit ordnungspolitischem Anspruch. Gesammelte Schriften Herausgegeben von Lars P. Feld und Christian Molitor}

[Telling Simple Truths. Endeavouring Regulatory Advisory. Collected Works.]

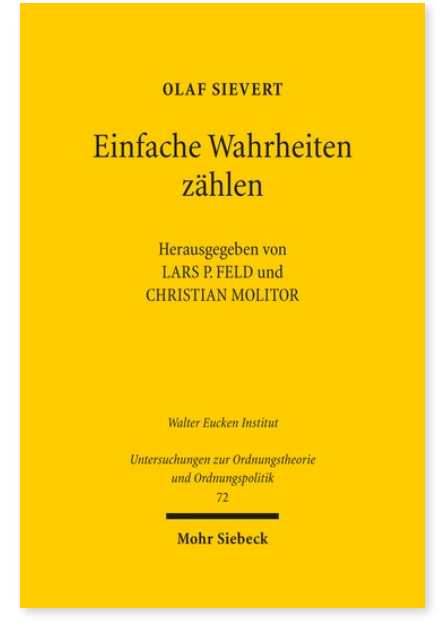

2022. $\mathrm{XVI}, 486$ pages. UOrd 72

ISBN 978-3-16-155244-1

cloth $119,00 €$

ISBN 978-3-16-155245-8

eBook PDF $119,00 €$
Published in German.

This volume features a selection of publications by Olaf Sievert, one of Germany's most influential twentieth century economists. He wrote passionate and original pleas in favour of prudent policies acknowledging the world's complexities and the limits of our knowledge. Above all, Sievert was an economic policy advisor whose career was closely associated with the German Council of Economic Experts. His writings are not only directed at a professional audience, but also to an interested general public. They thrive on a belief in the strength of good arguments and open discussion. Sievert argued early for supply side policies carried out at the beginning of the 1980s. For decades, he busied himself with monetary policy and became a prominent supporter of the European Monetary Union. He analysed globalisation and its economic impacts with foresight, and considered German unification with verve.

Olaf Sievert Geboren 1933; Studium der Volkswirtschaftslehre; 1963 Promotion; 1965-66 Generalsekretär des Sachverständigenrates zur Begutachtung der gesamtwirtschaftlichen Entwicklung; 1971-92 Professor für Nationalökonomie an der Universität des Saarlandes; 1993-98 Präsident der Landeszentralbank in den Freistaaten Sachsen und Thüringen.

Lars P. Feld Geboren 1966; Studium der Volkswirtschaftslehre; 1999 Promotion; 2002 Habilitation; seit 2010 Direktor des Walter Eucken Instituts Freiburg, Inhaber des Lehrstuhls für Wirtschaftspolitik und Ordnungsökonomik an der Albert-LudwigsUniversität Freiburg und Mitglied des Sachverständigenrates zur Begutachtung der gesamtwirtschaftlichen Entwicklung.

Christian Molitor Geboren 1965; Studium der Volkswirtschaftslehre; 1996 Promotion; danach im politischen Bereich und als Journalist tätig; seit 2000 in der Sparkassenorganisation beschäftigt; seit 2014 Geschäftsführer des Sparkassenverbandes Saar.

\section{Order now:}

https://www.mohrsiebeck.com/en/book/einfache-wahrheiten-zaehlen-9783161552441?no_cache=1

order@mohrsiebeck.com

Phone: +49 (0)7071-923-17

Fax: +49 (0)7071-51104 